\title{
Intergenerational Brand Transfer on Cosmetics Products
}

\author{
Su-Ding Ting \\ CMBA, Universiti Malaysia Sarawak (UNIMAS), MALAYSIA \\ "E-mail for correspondence: sudingchen@gmail.com
}

https://doi.org/10.18034/abr.v10i1.458

\begin{abstract}
The study examined intergenerational brand transfer from mother to daughter for cosmetics products using evolutionary psychology as the framework. Data were collected from 30 participants (14 mothers, 16 daughters) using in-depth semi-structured interviews. The results showed a strong intergenerational transfer of brand loyalty. Most of the daughters used either the full range $(25 \%)$ or a part of the range $(50 \%)$ of cosmetics products used by their mothers. A majority $(87.5 \%)$ of the daughters reported that they knew the cosmetics brands used by their mothers, and the interviews with their mothers showed that $75 \%$ of them accurately remembered the brands. The mothers' influence was achieved through brand visibility, daughters' trial use of the cosmetics, and the mothers acting as product suppliers. Price and product characteristics ranked the highest among the daughters' and mothers' considerations in purchasing cosmetics, showing that the daughters had adopted their mothers' behavior and thinking in product selection. The extended family also influenced the daughters' choice of cosmetics brands because of the close-knit community.
\end{abstract}

Key words: Intergenerational brand transfer, brand loyalty, brand visibility, brand knowledge

\section{INTRODUCTION}

In the $21^{\text {st }}$ century, globalization has driven brand strategy to become a significant component in marketing strategy and the development of global consumer products and brand (Motameni and Shahrokhi, 1998). Global consumer brands are significant for businesses, business image, and development of consumer products. A brand is recognized for its trademarks, its notable brand name, and the value that is attached to its products and services (Motameni and Shahrokhi, 1998). Hence, the consumer tends to form a sustainable long-term relationship with brands (Fournier, 1998).

The concept of brand loyalty has been researched by academics and practitioners in marketing and consumer behavior (Jensen and Hansen, 2006). Marketers seek to better understand consumer behavior to build and maintain their customer base. Brand managers seek to sustain the brand life for product growth, which enhances brand equity, which in turn is vital for the company's performance. Brand loyalty has positive effects on brand equity (Gil, Andres, and Salinas, 2007). Brand equity is vital for firms because it boosts the firm's financial performance and stock prices (Motameni and Shahrokhi, 1998). Brand equity enhances value of a brand name of a product (Aaker, 1991, as cited in Cobb-Walgren,
Ruble, and Donthu, 1995). Brand loyalty is defined as an act of repeated purchases by consumers over a period (Jensen and Hansen, 2006). Consumer's brand loyalty refers to customers' willingness to pay any price for the branded product as long as they are satisfied. Brand loyalty is built through advertising, which introduces the brand to consumers and thereafter, through constant use by family (Moore, Wilkie, and Lutz, 2002; Olsen, 1993), and this is known as intergenerational brand loyalty transfer. Consumers use the product or service and experience its benefits at an early age before they understand the advertising and promotions.

Studies have investigated the components of intergenerational brand loyalty such as brand knowledge, awareness, association (Gil, Andres, and Salinas, 2007), purchasing behavior (Moore-Shay and Lutz, 1988) and, lineage (Olsen, 1993). Based on the evolutionary psychology framework on intergeneration relations and human behavior, the children observe their parents' behavior through family socialization and learn to solve adaptive problems or situations faced by their parents as a way of natural selection. Due to persistent exposure, the children follow their parent's behavior and reasoning (Fiddick, Cosmides, and Tobby, 1995). Thus, it provides a 
base for the transfer of brand loyalty. The components of the brand transferred include brand preference and choice rules (Moore-Shay and Lutz, 1988), brand relationship (Fournier, 1998), brand knowledge (Kellar, 2003), brand information (Gil, Andres, and Salinas, 2007), and brand equity (Moore, Wilkie, and Lutz, 2002).

Thus far, research on intergenerational brand transfer are conducted on public and private products, as well as luxury and necessity products (Childers and Rao, 1992), and these include toothpaste and mayonnaise (Olsen, 1993), dairy products, oils, toiletries, and sports equipment. Moore-Shay and Lutz's (1988) study showed that there is an intergenerational transfer of brand equity within the mother and daughter dyads. Coetzee

(2019) found that transfer of brand loyalty to dishwashing liquid was sometimes across three generations in South Africa. In China, reverse socialization takes place, whereby the children influenced their parents to buy iPhone although it is expensive (Jiao \& Wei, 2019). Macharia (2019) investigated intergenerational brand transfer for cosmetics in Nairobi, Africa, but only from the perspective of the graduate students and their parents' perspectives were not included in the study. However, brand loyalty transfer for cosmetics products has not been researched in Malaysia. The research is relevant as Malaysia had recorded approximately US\$800 million sales in both cosmetics and toiletries in the year 2003, and the annual market growth is $13 \%$ annually (Malaysia_US Mission to Malaysia, Market Overview, 2005, para. 1). The advertising and promotion have become vital to cosmetics and toiletries products to create awareness towards the new products and to build brand loyalty among the consumers (Malaysia_US Mission to Malaysia, Market Overview, 2005, para. 1). However, the influence of brand loyalty is not only from advertising but also from consumer socialization such as relationships with peers, family, and extended family (Childers and Rao, 1992).

The study examined intergenerational brand transfer from mother to daughter for cosmetics products using evolutionary psychology as the framework.

\section{Method OF THE STUdY}

The data were collected from 30 participants in Sibu, Sarawak, which is an East Malaysian state on Borneo Kalimantan Island. The interview participants are 14 mothers and 16 daughters. Purposive sampling was conducted, and participants were sought from college, church, and other social contacts. Table 1 shows the demographic characteristics of the participants.

Perry (1998) stated that a minimum sample of 15 dyads is sufficient for in-depth interviews. Another consumer behavior study using in-depth interviews (Jiao and Wei, 2019) had only 20 participants, and they cited Boddy (2016) to explain that in-depth qualitative research with a small sample size can be "highly informative and meaningful" in representing the "picture of the whole population under review" (p. 426). Admittedly, the sample size may be too small for generalization of the findings to other settings, but it provides an indicator of trends in consumer behavior pertaining to cosmetics in settings similar to the present study. There was also a difficulty in getting a bigger sample size because both mothers and daughters had to be willing to participate in the study. Jiao and Wei (2019) acknowledged that none of their participants were parent-child pairs.

Table 1: Demographic information on participants

\begin{tabular}{|c|c|c|c|c|c|}
\hline \multirow{2}{*}{\multicolumn{2}{|c|}{ Variables }} & \multicolumn{2}{|c|}{ Mother } & \multicolumn{2}{|c|}{ Daughter } \\
\hline & & $\mathrm{n}$ & $\%$ & $\mathrm{n}$ & $\%$ \\
\hline Status & Mother/daughter & 14 & 46.7 & 16 & 53.3 \\
\hline \multirow[t]{6}{*}{ Age } & Below 21years & - & - & 5 & 31.3 \\
\hline & $21-30$ & - & - & 8 & 50.0 \\
\hline & $31-40$ & - & - & 2 & 12.5 \\
\hline & $41-50$ & 3 & 21.4 & 1 & 6.2 \\
\hline & $51-60$ & 6 & 42.9 & - & - \\
\hline & 60 above & 5 & 35.7 & - & - \\
\hline \multirow{2}{*}{$\begin{array}{l}\text { Marital } \\
\text { Status }\end{array}$} & Married & 14 & 100.0 & 2 & 12.5 \\
\hline & Single & - & - & 14 & 87.5 \\
\hline \multirow[t]{4}{*}{ Race } & Chinese & 12 & 85.8 & 13 & 81.3 \\
\hline & Malay & - & - & - & - \\
\hline & Iban & 1 & 7.1 & 1 & 6.2 \\
\hline & Others & 1 & 7.1 & 2 & 12.5 \\
\hline \multirow[t]{5}{*}{$\begin{array}{l}\text { Education } \\
\text { Level }\end{array}$} & $\begin{array}{l}\text { No formal } \\
\text { education }\end{array}$ & 2 & 14.3 & 1 & 6.3 \\
\hline & SPM/STPM & 8 & 57.1 & 5 & 31.2 \\
\hline & $\begin{array}{l}\text { Diploma/ } \\
\text { Adv.Diploma }\end{array}$ & 3 & 21.4 & 3 & 18.7 \\
\hline & Degree & 1 & 7.2 & 6 & 37.5 \\
\hline & Postgraduate & - & & 1 & 6.3 \\
\hline \multirow[t]{2}{*}{ Employment } & Employed & 6 & 42.9 & 7 & 43.7 \\
\hline & Unemployed & 8 & 57.1 & 9 & 56.3 \\
\hline \multirow{2}{*}{$\begin{array}{l}\text { Place of } \\
\text { Stay }\end{array}$} & With parents & & & 12 & 75.0 \\
\hline & With others & & & 4 & 25.0 \\
\hline \multirow{4}{*}{$\begin{array}{l}\text { Admire } \\
\text { mother }\end{array}$} & Moderate & & & 1 & 6.6 \\
\hline & Quite a lot & & & - & - \\
\hline & A lot & & & 6 & 37.5 \\
\hline & A great deal & & & 9 & 56.3 \\
\hline
\end{tabular}

Semi-structured face-to-face interviews are conducted using the interview guide in Appendix 1. The mothers were only asked Questions 1, 2, and 8. In addition to the interview, a questionnaire on demographic information was also used to find out the participants' age, marital status, race, level of education, profession, income, and place of residence (i.e., hostel or at home). Information on the level of the daughter's admiration for the mother was also obtained because it may provide a basis for explaining the effectiveness in the intergenerational transfer. No negative mother-daughter relationships were found (Table 1). 
The researcher explained the purpose of the study, voluntary participation, and confidentiality of responses to potential participants, and sought their verbal consent to participate in the study. Participants who agreed to participate in the study were contacted to fix an appointment for the face-to-face interview.

At the start of the interview session, the participants filled in a questionnaire on their demographic background. Filling in demographic information provides psychological comfort for the interviewees before the interview is conducted (Sekaran, 2003). The interviews conducted in a language preferred by the participants and were audio-recorded and last for about 30 minutes. The interview transcripts were analyzed to identify themes based on the interview questions. Then frequency distributions were computed.

\section{RESULTS}

The results showed that all the mothers were cosmetics users, and they had used all types of products such as cleanser, toner, moisturizer, lipstick, powder, and scrub. These products were from many brands, including local brands such as Gerverne and Ivy or imported brands such as Lancôme and Max Factor.

Daughter's memory on the cosmetics brands used by their mother

Table 2 shows the frequency and percentages of the daughters' memory on the cosmetics brands used by their mother in the past and at the present. Most (87.5\%) of the daughters remembered which cosmetics brand their mothers used because they had seen the product around their home. There was brand visibility in the home, leading the daughter to use the same brand as her mother, as shown in Excerpt 1:

\section{Excerpt 1}

Saw mother using it, Saw brand on the shelf, Product brand in and around the home, Saw catalogs, Just remember her using it, Saw brother recommends the product, Look through her products, Saw her collection of empty cosmetics bottles, Shopping together and using the same product as the mother.

A total of $37.5 \%$ of daughters could give the names of the cosmetics brands used by their mothers. They had seen family members involved in the direct sales of the cosmetics products (e.g., aunty, daughter, sister, or brother) recommending the product to their mother. Their mother subsequently recommended the product to them after it was proven to be good. As a result, they followed their mother's brand choice after trying it and finding it to suit them.
Table 2: Daughters' memory on cosmetics product brand used by mother

\begin{tabular}{|l|l|c|c|}
\hline Daughters' memory of mother's cosmetics & \multicolumn{2}{|c|}{ Daughter } \\
\cline { 3 - 4 } brand & $\mathrm{n}$ & $\%$ \\
\hline \begin{tabular}{l} 
Do you remember what $\begin{array}{l}\text { cosmetics products that } \\
\text { your mother uses? }\end{array}$ \\
\cline { 2 - 4 }
\end{tabular} & No & 14 & 87.5 \\
\hline $\begin{array}{l}\text { How many brands of } \\
\text { cosmetics products used by } \\
\text { your mother can you name? }\end{array}$ & All & 2 & 12.5 \\
\cline { 2 - 5 } & Some only & 6 & 37.5 \\
\hline
\end{tabular}

Table 3 summarizes the interview results on factors that caused daughters to remember the product brand used by their mother. Some daughters $(21.4 \%)$ did not recall the product brand because their mother seldom used it, but those who remembered said that they saw their mother using the product $(17.8 \%)$ or the product around the house such as on the shelf or dressing table (14.3\%). Some other daughters had seen catalogs or collection of empty bottles, or they had used it themselves. A dyad (Interviewee 21 and 22) had the habit of shopping together, and hence, they knew each other's product brand. Interestingly, some daughters did not remember the brand name but could describe the bottle size, shape, and its color (Interviewee 15).

Table 3: Frequencies showing factors influencing daughters' memory on the cosmetics brand used by their mother

\begin{tabular}{|l|l|c|c|}
\hline \multirow{2}{*}{ Category } & Factors & \multicolumn{2}{|c|}{ Daughter } \\
\cline { 2 - 4 } & & $\mathrm{n}$ & $\%$ \\
\hline \multirow{2}{*}{$\begin{array}{l}\text { No } \begin{array}{l}\text { memory } \\
\text { of brands }\end{array} \\
\text { Has } \\
\text { memory } \\
\text { of the } \\
\text { brands }\end{array}$} & $\begin{array}{l}\text { Don't remember because she } \\
\text { seldom uses cosmetics }\end{array}$ & 6 & 21.4 \\
\cline { 2 - 4 } & Don't know & 3 & 10.7 \\
\cline { 2 - 4 } & $\begin{array}{l}\text { I saw her using it } \\
\text { around the home }\end{array}$ & 5 & 17.8 \\
\cline { 2 - 4 } & $\begin{array}{l}\text { I also use the same products } \\
\text { myself }\end{array}$ & 3 & 10.7 \\
\cline { 2 - 4 } & I saw catalogs at home & 2 & 7.1 \\
\cline { 2 - 4 } & I just remember her using it & 1 & 3.6 \\
\cline { 2 - 4 } & $\begin{array}{l}\text { I saw my brother } \\
\text { recommending it }\end{array}$ & 1 & 3.6 \\
\cline { 2 - 4 } & I looked through her products & 1 & 3.6 \\
\cline { 2 - 4 } & I saw her bottle collection & 1 & 3.6 \\
\cline { 2 - 4 } & We went shopping together & 1 & 3.6 \\
\hline
\end{tabular}

\section{Daughters' reasons for their choice of cosmetics brand}

Table 4 shows that $50 \%$ of the daughters had used their mother's cosmetics products on a trial and error basis, and continued using it when they found that it to be good. Only $31.3 \%$ of the daughters used the entire range of products for the brand that their mother used, while another $31.3 \%$ used some products out of the full range of cosmetics used by their mothers. Nevertheless, Interviewee 4 was put off by the smell of the product. The other $50 \%$ of the daughters did not try the product because 
of certain product features such as anti-aging elements which is for older people.

Table 4: Daughters who used the same brand of cosmetics as their mother

\begin{tabular}{|l|l|c|c|}
\hline \multicolumn{2}{|l|}{$\begin{array}{l}\text { Daughters who used the same brand as } \\
\text { their mother }\end{array}$} & $n$ & $\%$ \\
\hline Tried the product & Yes & 8 & 50.0 \\
\cline { 2 - 4 } & No & 8 & 50.0 \\
\hline Used the product & Yes & 5 & 31.3 \\
\cline { 2 - 4 } & Some products & 5 & 31.3 \\
\cline { 2 - 4 } & None at all & 6 & 37.4 \\
\hline
\end{tabular}

Table 5: Frequencies showing daughters' reasons for using cosmetics products

\begin{tabular}{|l|l|c|c|}
\hline Category & $\begin{array}{l}\text { Daughters' reasons for using } \\
\text { the products }\end{array}$ & n & $\%$ \\
\hline \multirow{2}{*}{$\begin{array}{l}\text { Not } \\
\text { using } \\
\text { the same } \\
\text { products } \\
\text { as } \\
\text { mother }\end{array}$} & Its adults' products. & 8 & 14.6 \\
\cline { 2 - 4 } & I have my own products. & 6 & 11.0 \\
\cline { 2 - 4 } & $\begin{array}{l}\text { I get recommendations from } \\
\text { brother, friends and relatives. }\end{array}$ & 5 & 9.1 \\
\cline { 2 - 4 } & $\begin{array}{l}\text { I don't know what my mother } \\
\text { uses. }\end{array}$ & 3 & 5.5 \\
\cline { 2 - 4 } & She uses a mixture of brands. & 3 & 3.6 \\
\cline { 2 - 4 } & She uses anything people give. & 1 & 1.8 \\
\hline \multirow{4}{*}{$\begin{array}{l}\text { Using } \\
\text { the same } \\
\text { products }\end{array}$} & The price is reasonable. & 5 & 9.1 \\
\cline { 2 - 4 } mother & $\begin{array}{l}\text { I get recommendation from my } \\
\text { mother. }\end{array}$ & 4 & 7.3 \\
\cline { 2 - 4 } & My sister also uses it. & 3 & 5.5 \\
\cline { 2 - 4 } & It is not smelly. & 3 & 5.5 \\
\cline { 2 - 4 } & $\begin{array}{l}\text { The makeup looks good on } \\
\text { her. }\end{array}$ & 3 & 5.5 \\
\cline { 2 - 4 } & There are promotions. & 2 & 3.6 \\
\cline { 2 - 4 } & It has organic content. & 2 & 3.6 \\
\cline { 2 - 4 } & I introduce it to my mother. & 1 & 1.8 \\
\cline { 2 - 4 } & I see it from advertisement. & 1 & 1.8 \\
\cline { 2 - 4 } & It is not oily. & 1 & 1.8 \\
\cline { 2 - 4 } & I see it on the shelf. & 1 & 1.8 \\
\cline { 2 - 4 } & It is teenager's products. & 1 & 1.8 \\
\cline { 2 - 4 } & It is effective. & 1.8 \\
\cline { 2 - 4 } & I do not take care of my skin. & 1 & 1.8 \\
\cline { 2 - 4 } & I use what my mother bought. & 1 & 1.8 \\
\hline
\end{tabular}

Table 5 summarizes the daughters' reasons for using (or not using) the same brand of cosmetics as their mother. Some daughters did not use the same cosmetics brands as their mother. They perceived their mother's product as cosmetics for older people that contained ingredients like anti-aging or firming. They preferred to use teenager's products suited to their needs. For example, they considered ZA (Interviewee 28) and Eskinol (Interviewee 10) as young people's products, and Lancôme, Shiseido, and Amway's Nutrimetics as adult's products. Meanwhile, some daughters did not use the same brand as their mother because of their mother's habit of using mixed brands. These mothers kept changing brands because of reasons such as the unsuitability of products, promotion of products, and recommendation from some friends or relatives or they had found better brands. As a result, some of these daughters were not sure what brand their mothers were using. These mothers appeared to have low brand preferences and no brand loyalty. Their daughter developed their brand preference through trial and error and recommendation from all friends (Interviewee 10, 18, 11, 16), cousins (Interviewee 28), aunty (Interviewee 18), brother (Interviewee 13) and sisters (Interviewee 2, 8 and 10).

Table 5 shows that price and product characteristics topped the list of reasons given by daughters, who used the same cosmetics products as their mothers. Not all daughters regarded their mother's products as those that were meant for older people. Some daughters went shopping together with their mother, who paid for their cosmetics. Other daughters bought cosmetics using their monthly allowance or part-time work income. Thus, these daughters could only buy cosmetics at affordable prices.

\section{Mothers' responses on their daughters' knowledge of their cosmetics brand preferences}

Table 6 shows the mothers' responses on their daughters' knowledge of their cosmetics brand preferences. Earlier, Table 2 showed that most $(87.5 \%)$ of the daughters remembered the cosmetics brands used by their mothers, but a cross-checking with the mothers' interview results showed that only $75 \%$ of the daughters knew their mother's brand preference. For example, a mother (Interviewee 27) had a few brands but used one preferred brand more often. Her daughter was aware of the brands that she used because she had seen the cosmetics on the dressing table, but her daughter could name certain brands only. Only $25 \%$ of the daughters were unaware of their mother's cosmetics brand preference (Interviewee 6, 15, 16, and 26) because the mother changed the brand too often or had no brand preference. For one mother, the supply came from her son, who owned a cosmetics business (Interviewee 5). Another mother used gifts given by their daughter and daughter-in-law (Interviewee 14).

Table 6: Daughters' knowledge of mother's cosmetics brand preferences

\begin{tabular}{|l|l|c|c|}
\hline $\begin{array}{l}\text { Daughters' knowledge of mother's } \\
\text { cosmetics brand preferences }\end{array}$ & $\mathrm{n}$ & $\%$ \\
\hline $\begin{array}{l}\text { Daughter knows the } \\
\text { brand }\end{array}$ & Yes & 12 & 75.0 \\
\cline { 2 - 4 } $\begin{array}{l}\text { Daughter can name the } \\
\text { brand products }\end{array}$ & Correct & 4 & 25.0 \\
\cline { 2 - 4 } & Wrong & 6 & 65.5 \\
\hline Daughter has accurate & All correct & 2 & 12.5 \\
\cline { 2 - 4 } knowledge of brand & Some correct & 10 & 62.5 \\
\cline { 2 - 4 } & None correct & 4 & 25.0 \\
\hline
\end{tabular}


The similarity of cosmetics brand preferences of daughters and mothers

Table 7 shows the similarity between daughter and mother's cosmetics brand preferences. Only 25\% of daughters followed their mother's cosmetics brand preferences, while $50 \%$ used some of the brands used by their mother. The remaining 25\% used totally different brands of cosmetics, compared to their mother. For example, one mother-daughter pair both believed that organic-based products were better, evidence of the mother's influence. Another mother-daughter who used the same brand both said that the cosmetics brands were not smelly or oily (as shown in Excerpt 2).

Table 7: Daughter's brand preference compared against mother's cosmetics brand preferences

\begin{tabular}{|l|c|c|}
\hline $\begin{array}{l}\text { Similarity of daughter and mother's } \\
\text { cosmetics brand preferences }\end{array}$ & $\mathrm{n}$ & $\%$ \\
\hline Totally the same & 4 & 25.0 \\
\hline Some product brands are the same & 8 & 50.0 \\
\hline Not at all & 4 & 25.0 \\
\hline
\end{tabular}

\section{Excerpt 2:}

Not oily, Not smelly, Feel smooth, Cheap, Look at my needs, Beautician, Price reasonable, Effective, Sister also use, From the advertisement, Recommendation from mother, Recommendation from brother, friends, cousin and auntie, Quality, Promotions, Organic based, Good product, Suitability, Value for money, I use what mother bought, As simple as possible, I do not take care of my skin, Color, Establishment of companies. (Daughter)

Not oily, Not smelly, No need fragrance, Cheap price, Smooth feel, Suitable, Not allergic, Fulfil needs, Price reasonable, Advertisement, Look at my needs, Hardly consider, just buy and try, Effectiveness, Benefit recommended by daughter, Good beautician, Can use long, I use whatever, Organic based, Good customer services, Introduced by salesgirl, Good products, Recommendation by a son, Product quality, Value for money, Establishment of the firm, Promotions, Availability, Membership privilege and Any harm in the long run? (Mother)

Cosmetics is a personal product, and its effectiveness is often ambiguous because it may be effective for some and not for others. Table 8 shows that price topped the list of mothers' reasons for using certain cosmetics brands. Whether the mothers were working or not, price is a major factor in their choice of cosmetics brands. Mothers who mentioned product promotions were also thinking of the price and quality for the "value for money".

The second reason for the mothers to use certain cosmetics brands was the suitability of cosmetics products which is linked to product features. What is suitable for one may cause itchiness, redness, rashes, or other skin allergic reaction for others? The interviewees talked about the organic content of the cosmetics, and fragrance, smoothness, oiliness, and smell of products such as makeup, face care products, deodorants, and perfume.

Furthermore, the mothers were also influenced by recommendations from friends, peers, brothers, sisters, auntie, and cousins. They tended to believe these people as they had personally experienced it, and it treated their skin problems such as pimples and acne. As a result, there is a personal testimony of the effectiveness of the cosmetics products and that it can meet their needs at that point in time. These brands may not be established brands, which turned out to be low priority among the interviewees.

Generally, most interviewees had specific reasons for their choice of cosmetics brands, which included product characteristics, promotions, convenience in shopping, and product establishment in the market. However, a handful were not choosy over brands, and bought what was easily available or on offer. A comparison with the daughters' reasons for their purchasing decisions (Table 5) showed that price and product characteristics were also the main considerations, indicating the daughters had adopted their mothers' purchasing behavior and rationale.

Table 8: Frequency of mothers' reasons for using the cosmetics products

\begin{tabular}{|c|c|c|c|}
\hline $\begin{array}{l}\text { Category of } \\
\text { reasons }\end{array}$ & $\begin{array}{l}\text { Mothers' reasons for } \\
\text { using cosmetics } \\
\text { products }\end{array}$ & $\mathrm{n}$ & $\%$ \\
\hline \multirow[t]{2}{*}{ Price } & Reasonable price & 13 & 21.6 \\
\hline & $\begin{array}{ll}\text { Promotions } & \text { (seen } \\
\text { advertisements) }\end{array}$ & 5 & 8.3 \\
\hline \multirow{9}{*}{$\begin{array}{l}\text { Product } \\
\text { characteristics }\end{array}$} & Suitable, not allergic & 7 & 11.7 \\
\hline & Effective & 4 & 6.7 \\
\hline & Good products & 4 & 6.6 \\
\hline & Can use for a long time & 3 & 5.0 \\
\hline & Not oily (smooth) & 3 & 5.0 \\
\hline & Not smelly & 1 & 1.7 \\
\hline & No harm in the long run & 1 & 1.6 \\
\hline & Organic-based & 1 & 1.7 \\
\hline & No need fragrance & 1 & 1.7 \\
\hline \multirow[t]{2}{*}{$\begin{array}{l}\text { Recommended } \\
\text { product }\end{array}$} & $\begin{array}{l}\text { Recommendation by } \\
\text { family }\end{array}$ & 3 & 5.0 \\
\hline & Introduced by salesgirl & 3 & 5.0 \\
\hline \multirow[t]{4}{*}{$\begin{array}{l}\text { Not choosy } \\
\text { over brand }\end{array}$} & $\begin{array}{l}\text { Hardly consider, just } \\
\text { buy and try }\end{array}$ & 2 & 3.3 \\
\hline & Fulfill needs & 2 & 3.3 \\
\hline & Availability & 2 & 3.3 \\
\hline & I just use whatever & 1 & 1.7 \\
\hline \multirow[t]{3}{*}{$\begin{array}{l}\text { Established } \\
\text { brand }\end{array}$} & $\begin{array}{l}\text { Customer services (e.g., } \\
\text { beautician) }\end{array}$ & 2 & 3.3 \\
\hline & Establishment of the firm & 1 & 1.7 \\
\hline & Membership privilege & 1 & 1.7 \\
\hline
\end{tabular}




\section{Discussion}

Mothers are a force in fostering loyalty to cosmetics brands, as shown by one-quarter of the daughters who used the same cosmetics brands as their mothers. The influence of mothers on daughters is achieved through brand visibility, shopping together, regular interactions, and personal visits - even when the daughters are grown up. In the present study, those daughters who did not live with their mother were still inclined to use the same cosmetics product as their mother because their mothers acted as suppliers of the products. Four daughters who did not live with their parents were either married or receiving tertiary education at the time of the study. Parents play the role as product suppliers when they give certain products as gifts to their children, thereby reinforcing their influence on their children (Moore, Wilkie, and Lutz, 2002).

The evolutionary psychology framework explains that the important influence due to the attachment to a person or specific object is formed since early childhood (Esch, Langner, Schmitt, and Geus, 2006). The transfer of brand loyalty is engendered by close relationship with the trusted persons (Elliot and Yannopoulou, 2007). Besides the mother, the extended family also influences the daughter's choice of cosmetics brands because families are close-knit and communalistic in Sibu, where the study is conducted. The interviews revealed that there was familial influence from extended families such as cousin and aunt, and even from brothers. In Asian families, the younger generation respects the older relatives, and listen to their recommendation. Similarly, Childers and Rao (1992) found that in Thailand, there is a strong intergenerational influence in brand loyalty transfer for private necessities, but the influence is lower for luxury goods. Childers and Rao (1992) concluded that since Thai families live in communalistic societies, extended family members tend to influence consumer decisions.

However, the present study showed that only $25 \%$ of the daughters used all the brands that their mother used. The intergenerational brand transfer was not complete for $50 \%$ of the daughters, that is, the mother's influence on their daughter's brand loyalty was partial. The partial intergenerational brand transfer could be due to mothers' lack of emphasis on educating their daughters about the usage and purchase of cosmetics products. Out of the 14 mothers studied, there was only one mother who committed herself to teaching her daughter about the importance of skin protection for the long run by using organic-based products. This mother was different because she had seen people who suffered from using the wrong cosmetic products. In the context of evolutionary psychology, the mother exhibited an adapted behavior and thinking in selecting the cosmetic brand and the product ingredients to mitigate a problem faced by her friends to prevent a recurrence of the same problem in her daughters. As a result, the mother had a new behavior, that is, to use only organic-based products and she succeeded in influencing her daughter to do likewise. Besides this mother, there are a few other mothers who explicitly recommended certain brands and products to their daughter, but not all succeeded in influencing their daughters to use the same range of cosmetics products. The influence was not always about the benefits of brands. The mothers' influence was also in the form of creating negative impressions on some products and brands, thereby influencing their daughters' brand preferences and purchasing factors. There is more likelihood that mothers and daughters share specific brand preferences and shopping strategies than abstract beliefs about the marketplace (Moore-Shay and Lutz, 1988).

This study found intergenerational transfer of cosmetics brand loyalty from mothers to daughters in $75 \%$ of the cases studied. Based on Childers and Rao's (1992) study, private necessities are subject to higher intergenerational transfer than luxury goods. Cosmetic is a personal product, but whether it is a necessity or luxury is subjective. In this study, there was one mother who was willing to spend thousands on cosmetics while another preferred their cosmetics products to cost less than RM30.00 (less than USD7 at a currency conversion rate of $1 \mathrm{USD}=\mathrm{RM} 4.36)$. Price ranked the highest among the mothers' reasons for using certain cosmetics brands, followed by product features. Therefore, the cosmetics brand can fall under private necessities or luxury depending on how each individual perceives the product as to whether it meets their needs only or it serves as a status symbol, especially among peers. Price and product quality are also the two most important considerations when graduate students in Nairobi purchase cosmetics (Macharia, 2019). The graduate students tend to buy cosmetics products used or recommended by their parents, and the parents' influence began as early as childhood. Cosmetics brands selected resonate with their social status but many of them do not have the luxury to buy expensive brands they desire. For necessities such as dish washing liquid, Coetzee (2019) found a strong generational transfer of brand loyalty, and brand switching only occurs when there are changes in price and availability of the preferred brand. For cell phones, the Apple iPhone is considered a luxury product in China. Jiao and Wei (2019) found that when children gave their used iPhone to their parents, the parents were influenced to think highly of the phone's quality and value the close family relationship and social status that it symbolizes. This is an example of intergenerational transfer of brand loyalty for a luxury product from children to parents. Reverse socialization in consumer purchasing behavior needs to be further investigated in the digital area, where the younger generation is more technology-savvy than their parents. 


\section{CONCLUSION}

The study on intergenerational brand transfer from mother to daughter for cosmetics products showed that mothers influenced their daughter's choice of cosmetics brands. Most of the daughters remembered the cosmetics brand used by their mother, showing brand visibility. This brand knowledge is due to the daughters' exposure to the brand while living with their parents. Quite many daughters knew the factors that their mother considered when buying cosmetics. Elsewhere, Moore-Shay and Lutz (1988) found that the daughters were accurate in identifying their mothers' brand preferences due to brand visibility around their home. The finding is in line with the evolutionary psychology framework in that the mothers' influence on the daughters' the brand preferences and purchasing factors is quite strong. The daughters had adopted their mothers' behavior and thinking in product selection to mitigate the problems faced in their usage of a certain cosmetic brands. Nevertheless, the findings are generalizable only to contexts similar to the present study because of the small sample size. Future research in the area of consumer behavior should focus on intergenerational transfer of brand loyalty for a wider range of products and factors in brand synthesis (Kellar, 2003). Further, reverse socialization should also be investigated because children can influence their parents' purchasing behavior.

\section{REFERENCES}

Aaker, D.A. (1991). Managing brand equity. New York: Free Press.

Boddy, C.R. (2016). Sample size for qualitative research. Qualitative Market Research: An International Journal, 19 (4), 426-432.

Childers, T.L. and Rao, A.R. (1992). The influence of familial and peer-based reference groups on consumer decisions. Journal of Consumer Research, 19, 198-211.

Cobb-Walgren, C.J., Ruble, C.A. and Donthu, N. (1995). Brand equity, brand preference, and purchase intent. Journal of Advertising, XXIV (3), 25-40.

Coetzee, Q. (2019). Analysing generational transfer of brand loyalty in the dishwashing liquid product category, in the Western Cape Province. (Unpublished Masters thesis, University of Capetown, Africa).

Cosmides, L. and Tooby, J. (1997). Evolutionary psychology: A primer. Santa Barbara: Center of Evolutionary Psychology, University of California.

Elliot, R. and Yannopoulou, N. (2007). The nature of trust in brands: A psychosocial model. European Journal of Marketing, 41(9/10), 988-998.

Esch, F.R., Langer, T., Schmitt, B.H., and Geus, P. (2006). Are brands forever? How brand knowledge and relationships affect current and future purchases. Journal of Product and Brand Management, 15(2), 98-105.

Fiddick, L., Cosmides, L., and Tooby, J. (1995). Priming Darwinian algorithms: Converging lines of evidence for domain-specific inference module. Paper presented at the Annual Meeting of the Human Behavior and Evolution Society, Santa Barbara, CA.

Fournier, S. (1998). Consumer and their brands: Developing relationship theory in consumer research. Journal of Consumer Research, 24, 343-372.

Gil, R.B., Andres, E.F. and Salinas, E.M. (2007). Family as a source of consumer-based brand equity. Journal of Product and Brand Management, 16(3), 188-199.

Jensen, J.M. and Hansen, T. (2006). An empirical examination of brand loyalty. Journal of Product and Brand Management, 15(7), 442-229.

Jiao, R., and Wei, J. (2020). Brand expansion through reverse socialization: an example of iPhone in China. Qualitative Market Research: An International Journal, 23(1), 1-20.

Keller, K.L. (2003). Brand synthesis: The multidimensionality of brand knowledge. Journal of Consumer Research, 29, 595-600.

Macharia, K. (2019). Factors influencing consumer choice of cosmetics: A case of United States International University Africa Graduate Students (Unpublished Masters thesis, United States International University-Africa, Africa).

Moore Shay, E.S. and Lutz, R.J. (1988). Intergenerational influences in the formation of consumer attitudes and beliefs about the marketplace: Mothers and daughters. Advances in Consumer Research, 15, 461-467.

Moore, E.S., Wilkie, W.L. and Lutz, R.J. (2002). Passing the torch: Intergenerational influences as a source of brand equity. Journal of Marketing, 66, 17-37.

Motameni, R. and Shahrokhi, M. (1998). Brand equity valuation: A global perspective. Journal of Product and Brand Management, 7(4), 275-290.

Olsen, B. (1993). Brand loyalty and lineage: Exploring new dimensions for research. Advances in Consumer Research, 20, 575-579.

Perry, C. (1998). Processes of a case study methodology for postgraduate research in Marketing. European Journal of Marketing, 32, 785.

Sekaran, U. (2003). Research methods for business: A skill-building approach (4th ed.). USA: John Wiley and Sons.

$$
--0--
$$




\section{Appendix 1: Semi-structured interview guide}

1. What cosmetics products do you use?

2. What brands do you use for each of the cosmetics products?

3. Do you remember what cosmetics products that your mother uses?

4. What are the brands for each of the cosmetics products that your mother uses?

5. Why do you remember these products and the brands?

6. Have you ever used the same brand as your mother did?

- If your answer is "yes," which of the products that you use is the same?

- Why did you use the same brand as your mother did?

- If your answer is "no," why do you not use the same brand?

7. Do you know what factors considered by your mother in buying cosmetics products? Then, what are the factors considered by her?

8. What factors do you consider when buying cosmetics products? 